\title{
A new species of Aelurillus Simon, 1884 (Aranei: Salticidae) from Thailand, with the first description of the male of A. afghanus Azarkina, 2006
}

\author{
Новый вид Aelurillus Simon, 1884 (Aranei: Salticidae) из Таиманда, \\ с описанием самца A. afghanus Azarkina, 2006
}

\author{
Galina N. Azarkina \\ Г.Н. Азаркина
}

\begin{abstract}
The Laboratory of Systematics of Invertebrate Animals, The Institute of Systematics and Ecology of Animals, Siberian Branch Russian Academy of Sciences, Frunze Street 11, Novosibirsk 630091, Russia. E-mail: urmakuz@gmail.com

Лаборатория систематики беспозвоночных животных, Институт систематики и экологии животных СО РАН, ул. Фрунзе, 11, Новосибирск 630091 Россия.
\end{abstract}

KEY WORDS: Araneae, jumping spiders, SE Asia, the 'minimontanus' species group, spiders.

КЛЮЧЕВЫЕ СЛОВА: Araneae, пауки-скакунчики, Юго-Восточная Азия, группа видов 'minimontanus', пауки.

ABSTRACT. A new species of Aelurillus Simon, 1884 from Thailand — A. thailandicus sp.n. $\left(0^{7}\right.$, , Phitsanulok and Nakhon Ratchasima Provinces) - is diagnosed and described. The male of Aelurillus afghanus Azarkina, 2006 is described for the first time. The 'minimontanus' species group is proposed and described. An identification key to all the species of this group is given, and collecting localities of all of them are mapped.

How to cite this article: Azarkina G.N. 2019. A new species of Aelurillus Simon, 1884 (Aranei: Salticidae) from Thailand, with the first description of the male of A. afghanus Azarkina, 2006 // Arthropoda Selecta. Vol.28. No.3. P.408-416. doi: 10.15298/arthsel. 28.3.05

РЕЗЮМЕ. Из Таиланда описан новый вид Aelurillus Simon, $1884-A$. thailandicus sp.n. (O' винции Пхитсанулок и Накхонратчасима). Впервые описан самец Aelurillus afghanus Azarkina, 2006. Выделена группа видов 'minimontanus'. Приведён определительный ключ и прокартированы находки всех видов группы.

\section{Introduction}

Currently, 42 species of Salticidae are known from Thailand [Metzner, 2019; WSC, 2019], which is a surprisingly low number, for instance, compared to the salticid fauna of Vietnam which is the best studied in the Indochina Peninsula accounting for 122 species [Żabka, 1985; Metzner, 2019; WSC, 2019]. Thus, despite the territory of Thailand is one and half times larger than that of Vietnam, its known salticid fauna is yet three times smaller. It is very likely that many common salticid species than have been recorded from Maynmar, southern China or Vietnam will be found in Thailand, for instance, Burmattus pococki (Thorell, 1895), Phintella debilis (Thorell, 1891), etc. [Metzner, 2019]. One species, Stenaelurillus abramovi Logunov, 2008, which was described from southern Vientnam, was later found in Thailand [Logunov, Azarkina, 2018].

First records of jumping spiders from Thailand were made by Giebel [1863] who described four new species in two genera, with all of them being later considered nomina dubia by Roewer [1955]. The majority of salticid species have been recorded/described from Thailand in recent years [Benjamin, 2004, 2010; Logunov, Hereward, 2006; Logunov, Azarkina, 2008, 2018; Prószyński, Deeleman-Reinhold, 2012; Chotwond, Tanikawa, 2013; Yamasaki, Ahmad, 2013; Logunov, Marusik, 2014; Logunov, 2017, 2019; Żabka, Gardzińska, 2017].

To date, only two Aelurillina species have been reported from Indochina: Phlegra pisarskii Żabka, 1985, which was described from Vietnam and later found in the Chinese province Guangxi (but the latter finding might belong to a different species) [Żabka, 1985; Zhang et al., 1992] and S. abramovi. The third Oriental aelurillina species, Aelurillus thailandicus sp.n., is described in the present paper.

The aims of this paper are: (1) to describe a new Aelurillus species from Thailand; (2) to describe the male of $A$. afghanus Azarkina, 2006 for the first time; (3) to propose a new 'minimontanus' species group in the genus Aelurillus; (4) to provide an identification key to all the species of the 'minimontanus' group; and (5) to map distribution of all these species. 


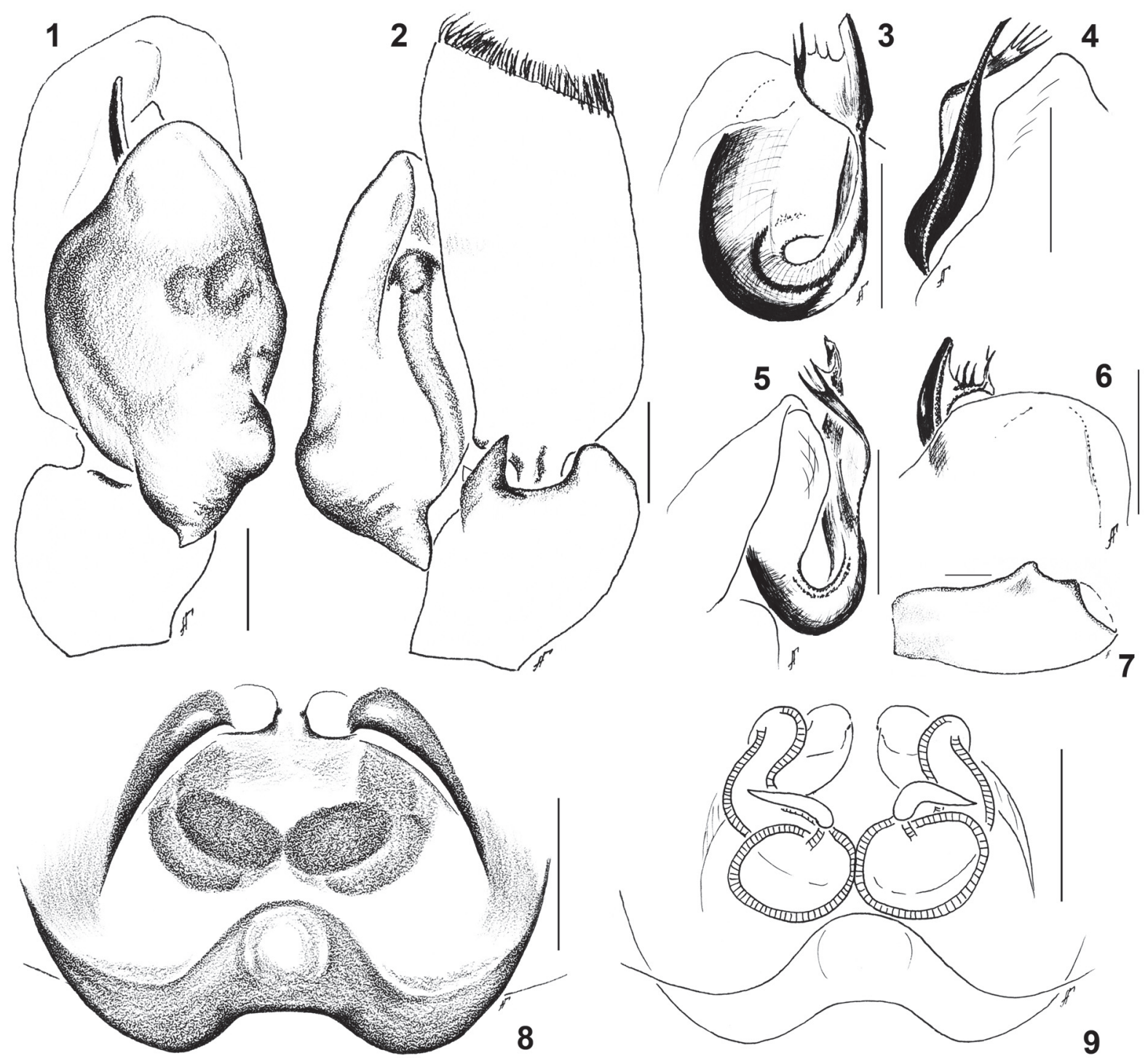

Figs 1-9. Copulatory organs of Aelurillus afghanus Azarkina, 2006: 1 - left palp, dorsal view; 2 - ditto, retrolateral view; 3 - ED, dorsal view; 4 - ditto, prolateral view; 5 - ditto, retrolateral view; 6 - ditto, ventral view; 7 - left palpal femur, retrolateral view; 8 epigyne, ventral view; 9 - spermathecae, dorsal view. Scale bars: $0.1 \mathrm{~mm}$.

Рис. 1-9. Копулятивные органы Aelurillus afghanus Azarkina, 2006: 1 - левая пальпа, вентрально; 2 - то же, ретролатерально; 3 - эмболюсный отдел, дорсально; 4 - то же, пролатерально; 5 - то же, ретролатерально; 6 - то же, вентрально; 7 - бедро левой пальпы, ретролатерально; 8 - эпигина, вентрально; 9 - сперматека, дорсально. Масштаб: 0,1 мм.

\section{Material and methods}

The studied specimens are shared between the following museums (curators in parentheses): BMNH Natural History Museum, London, UK (J. Beccaloni); ISEA - Institute of Systematics and Ecology of Animals, Novosibirsk, Russia (G.N. Azarkina); NMP National Museum of Prague, Czech Republic (P. Dolejš); and ZMMU — Zoological Museum of the Moscow State University, Russia (K.G. Mikhailov).

A total of 10 Aelurillus specimens is studied. The specimens were examined in ethanol and their coloration refers to that of the preserved specimens. All draw- ings were made with the aid of a reticular eyepiece attached to a MBS-10 stereomicroscope. The epigynes were detached and macerated in $20 \% \mathrm{KOH}$ solution overnight. Photographs were taken by means of a AxioCam MRc5 (for male of $A$. afghanus) and Canon EOS 550D (for $A$. thailandicus sp.n. and female of $A$. afghanus) attached to Zeiss Stemi 2000-C. Focal planes of single image stacks were combined using the Helicon Focus 6.3 software at the Institute of Systematics and Ecology of Animals. All drawings were edited and assembled in Adobe Photoshop CS5.

Comparative material: Paratypes of A. minimontanus Azarkina, 2002 (Figs 37-40): $24 \sigma^{7} \sigma^{7}, 4$ OP (ISEA, 000.705), $7 \sigma^{7} \sigma^{7}, 5$ 웅 (ISEA, 000.710), India, Sissu Vil. ( $\left.32^{\circ} 28.1^{\prime} \mathrm{N}, 77^{\circ} 07.9^{\prime} \mathrm{E}\right), 3150$ 
$3500 \mathrm{~m}$ a.s.1., south facing stony slope and the first river terrace, dry meadow with Artemisia (hand collecting), 8-10.06.1999, Yu.M. Marusik.

The terminology follows Azarkina \& Zamani [2019] and Logunov \& Azarkina [2018]. Abbreviations used in the text are as follows: ALE - anterior lateral eyes, AME - anterior median eyes, ap - apical, $\mathrm{CO}$ - copulatory openings, $\mathrm{d}$ dorsal, ED - embolic division, EP - epigynal pocket, EW epigynal wings, Fm - femur, ID — insemination duct, $\mathrm{Mt}$ - metatarsus, pr - prolateral, PLE - posterior lateral eyes, PS - primary spermatheca, Pt — patella, RTA retrolateral tibial apophysis, SR — salticid radix, TA terminal apophysis, $\mathrm{Tb}$ - tibia, $\mathrm{rt}$ - retrolateral, $\mathrm{V}$ ventral. All measurements are in $\mathrm{mm}$. For leg spination the system adopted is that used by Ono [1988].

\section{Taxonomy}

\section{Genus Aelurillus Simon, 1884}

Type species: Aelurillus v-insignitus (Clerck, 1758)

The genus Aelurillus includes 73 valid species (including two subspecies) [WSC, 2019]. The new species, $A$. thailandicus sp.n., together with A. afghanus Azarkina, 2006 and A. minimontanus Azarkina, 2002, form a separate 'minimontanus' species group, which differs from other species groups (see Azarkina [2006a]) in the following characters: (1) The terminal apophysis and the membrane connecting TA and the embolus possess very long teeth (Figs 3-6, 28$31,37-40)$. Almost all the representatives of the 'aeruginosus' species group (e.g., A. blandus (Simon, 1871), see figs 4-7 in Azarkina [2002]; A. concolor Kulczyński, 1901, see figs 12-25 in Azarkina \& Mirshamsi [2014]) and some species of the 'luctuosus' species group (e.g., A. improvisus Azarkina, 2002 and A. minutus Azarkina, 2002, see figs 2325 and 69 in Azarkina [2002]) also have teeth, but their teeth are very short and sometimes are inconspicuous. (2) The dorsal tibial apophysis very short, slightly bent ventrad and with a blunt tip (Figs 2, 21, 27; cf. fig. 60 in Azarkina [2002]). (3) The epigyne resembles those of species from the 'm-nigrum' group (cg. figs 39 and 79 in Azarkina [2002]; figs 1-3 in Azarkina et al. [2018]), but the copulatory openings are situated at a wider distance from each other (cf. Figs 8, 35 and fig. 56 in Azarkina [2002] and fig. 3 in Azarkina [2006b]).

\section{Key to the 'MINIMONTANUS' SPECIES GROUP}

1. Males ... 2

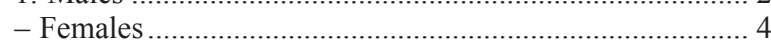

2. TA dorsally with a retrolateral curve, so that the apical part of the ED looks like a wineglass (Figs 3, 28) ...... 3

- TA without a retrolateral curve (Fig. 38) A. minimontanus

3. Embolus with three apical protuberances (arrowed in Figs 29, 31) A. thailandicus sp.n.

- Embolus without apical protuberances (Figs 4-5) A. afghanus

4. CO and EW are situated horizontally, EP high, occupying $4 / 5$ of the epigynal height from its basis to CO (see fig. 56 in Azarkina [2002]), spermathecae simple, ID short, with a small number of twists (see figs 57-58 in Azarkina [2002]) A. minimontanus

- $\mathrm{CO}$ and EW are situated at a $45^{\circ}$ angle, EP low (Figs 8, 35)

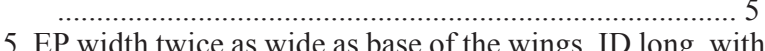
numerous twists (Fig. 36) ............. A. thailandicus sp.n.
- EP width 1.5 times broader than base of the wings, spermathecae simple, ID short, with a small number of twists (see Fig. 9 and fig. 1 in Azarkina [2006b]) ... A. afghanus

\section{Aelurillus afghanus Azarkina, 2006}

Figs 1-11, 18-21, Map.

Aelurillus afghanus Azarkina, 2006: 64, figs 1-4 (D $\mathrm{D}_{+}$, holotype + from NMP, examined).

TYPES. HoLOTy $O$ (NMP) from Afghanistan, Nangarhar Province, Jalalabad District, $12-20 \mathrm{~km}$ SE of Jalalabad (c. $34^{\circ} 19^{\prime} \mathrm{N}$, 70³6'E), $600 \mathrm{~m}$ a.s.1., 7.03.1966, Povolný \& Tenora. - PARAType: 1 ( NMP), Afghanistan, Nangarhar Province, Sherzad District, c. $35 \mathrm{~km} \mathrm{SW}$ from Jalalabad, Nimla (c. $34^{\circ} 17^{\prime} 46^{\prime \prime} \mathrm{N}, 70^{\circ} 06^{\prime} 04^{\prime \prime} \mathrm{E}$ ), 2.05.1963, collector unknown.

MATERIAL. PAKISTAN: 1 (ZMMU, Ta-8075) Peshawar Islamabad Road, bridge across Indus River, c. $60 \mathrm{~km}$ E of Peshawar $\left(33^{\circ} 53^{\prime} \mathrm{N}, 72^{\circ} 18^{\prime} \mathrm{E}\right), 30.08-1.09 .2005$, S.V. Ovtchinnikov; 4 $\sigma^{\top} \sigma^{\top}(\mathrm{BMNH})$, Wah (c. $\left.33^{\circ} 46^{\prime} \mathrm{N}, 72^{\circ} 43^{\prime} \mathrm{E}\right)$, waste ground in garden, 5.04.1958, A.M. Wild.

DIAGNOSIS. By the body coloration and conformation of the copulatory organs, the male of A. afghanus is similar to that of $A$. thailandicus sp.n., but differs from it in fine details of the ED: (1) the thick embolus without apical protuberances in A. afghanus (Figs 4-5) compared to the thinner embolus with three triangle apical protuberances in A. thailandicus sp.n. (arrowed in Figs 29, 31); and (2) the embolic tip is bent retrolaterad in A. afghanus (Fig. 6), whereas it is bent prolaterad in $A$. thailandicus sp.n. (Fig. 30). By conformation of the epigyne, the female of $A$. afghanus is similar to those of $A$. thailandicus sp.n. and $A$. minimontanus, but differs from both in the EP shape: EP low, its width 1.5 times broader than the wing base in A. afghanus (see Fig. 8 and fig. 1 in Azarkina [2006b]); EP wide, its width 2 times broader than the wing base in $A$. thailandicus sp.n. (Fig. 35); and EP high, occupying 4/5 of the epigynal height from its basis to $\mathrm{CO}$ in A. minimontanus (fig. 56 in Azarkina, 2002). By conformation of the vulva, A. afghanus is most similar to that of $A$. minimontanus: the spermathecae in both species are simple, with 3-4 twists, terminal parts of the spermathecae near FD are situated horizontally in $A$. afghanus (see Fig. 9 and fig. 1 in Azarkina [2006b]), whereas they are vertical in A. minimontanus (see fig. 57 in Azarkina [2002]).

DESCRIPTION. MALE: Carapace 1.80 long, 1.40 wide, 1.10 high at PLE. Ocular area 0.90 long, 1.00 wide anteriorly and 0.95 wide posteriorly. Diameter of AME 0.25. Abdomen 1.60 long, 1.10 wide. Cheliceral length 0.40. Clypeal height 0.25 . Length of leg segments: I $0.80+0.45+0.60+$ $0.45+0.35$ (2.65); II $0.75+0.45+0.50+0.40+0.35$ $(2.45)$; III $1.20+0.55+0.65+0.65+0.35(3.40)$; IV $0.90+$ $0.60+0.80+0.90+0.50$ (3.70). Leg spination: I: Fm d $1-$ 1-4; Pt pr and rt 1; Tb d 1-0-0, pr 1-1-1, rt 1-1-0, v 2-2-2 ap; Mt pr and rt 1-1 ap, v 2-2 ap. II: Fm d 1-2-5; Pt pr and rt 1; Tb d 1-0-0, pr 1-1-1, rt 1-1-0, v 1-1-2 ap; Mt pr and rt 1-1ap, v 2-2 ap. III: Fm d 1-2-5; Pt pr and rt 1; Tb d 1-00 , pr and rt 1-1-1-1, v 1-0-2 ap; Mt d 1-0-0, pr and rt 10-2 ap, v 2-0-2 ap. IV: Fm d 1-1-5; Pt pr and rt 1; Tb d 1$0-0$, pr and rt 1-1-1-1, v 1-0-2 ap; Mt d 1-1-0, pr 1-1-2 ap, rt 1-0-2 ap, v 1-1-2 ap. Coloration (in alcohol). Carapace brown to dark brown, dorsally with two white longitudinal bands, laterally with white broad bands, marginally with white hairs (Fig. 10). Eye field with white scales, with two brown stripes running from AMEs towards the back side of eye field. Cheeks brown, clypeus dark brown, covered with dense white hairs. There are two narrow, longitudinal stripes of brown recumbent scales and a white narrow 


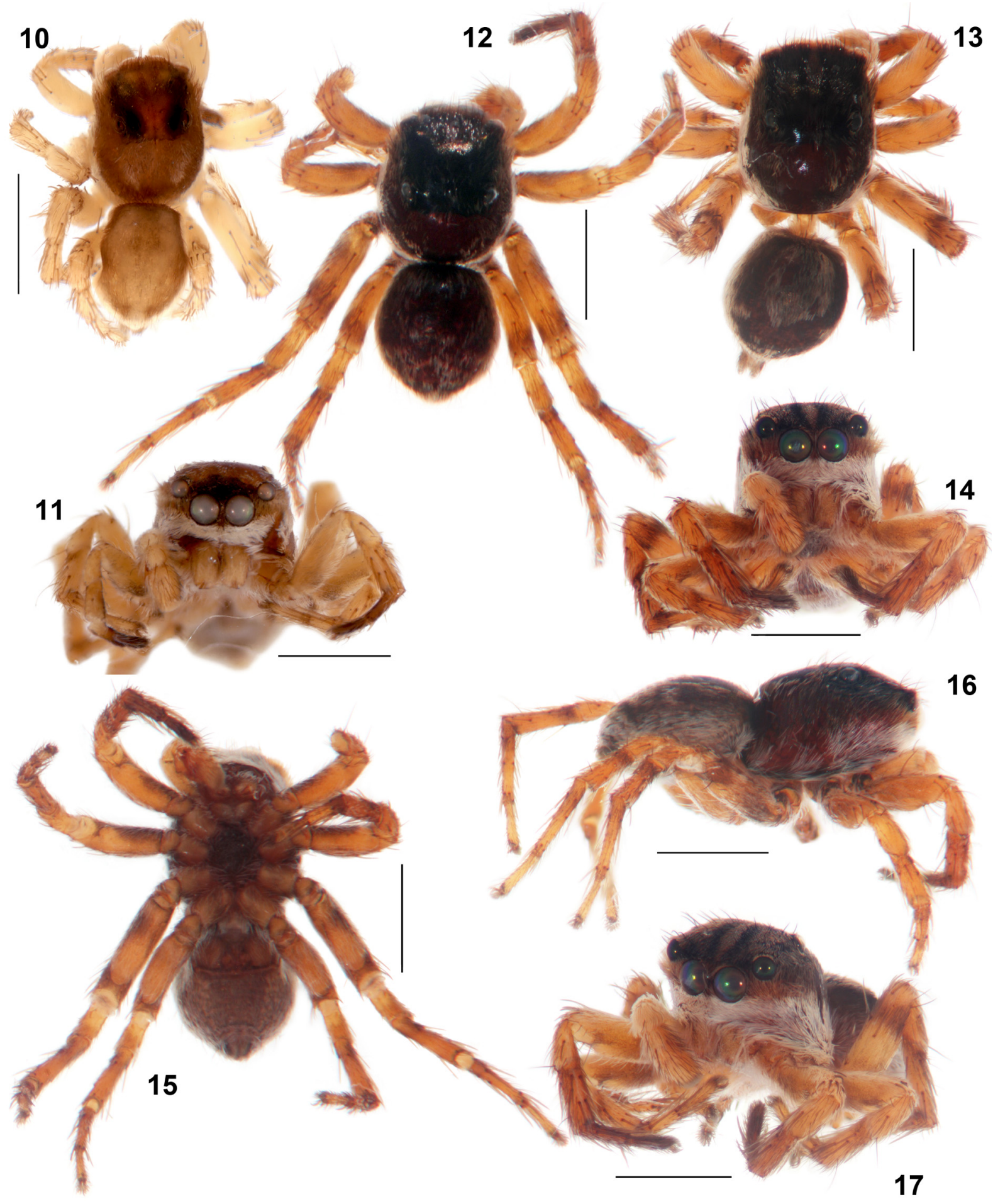

Figs 10-17. General appearance of males of Aelurillus afghanus Azarkina, 2006 (10-11) and A. thailandicus sp.n. (12, 15-16 holotype; 13-14, 17 paratype): 10, 12-13 - dorsal view; 11, 14 - frontal view; 15 - ventral view; 16 - lateral view; 17 - laterofrontal view. Scale bars: $1 \mathrm{~mm}$.

Рис. 10-17. Внешний вид самцов Aelurillus afghanus Azarkina, 2006 (8-9) и A. thailandicus sp.n. (12, 15-16 голотип; 13-14, 17 паратип): 10, 12-13 - дорсально; 11, 14 - фронтально; 15 - вентрально; 16 - латерально; 17 - латеро-фронтально. Масштаб: 1 мм. 


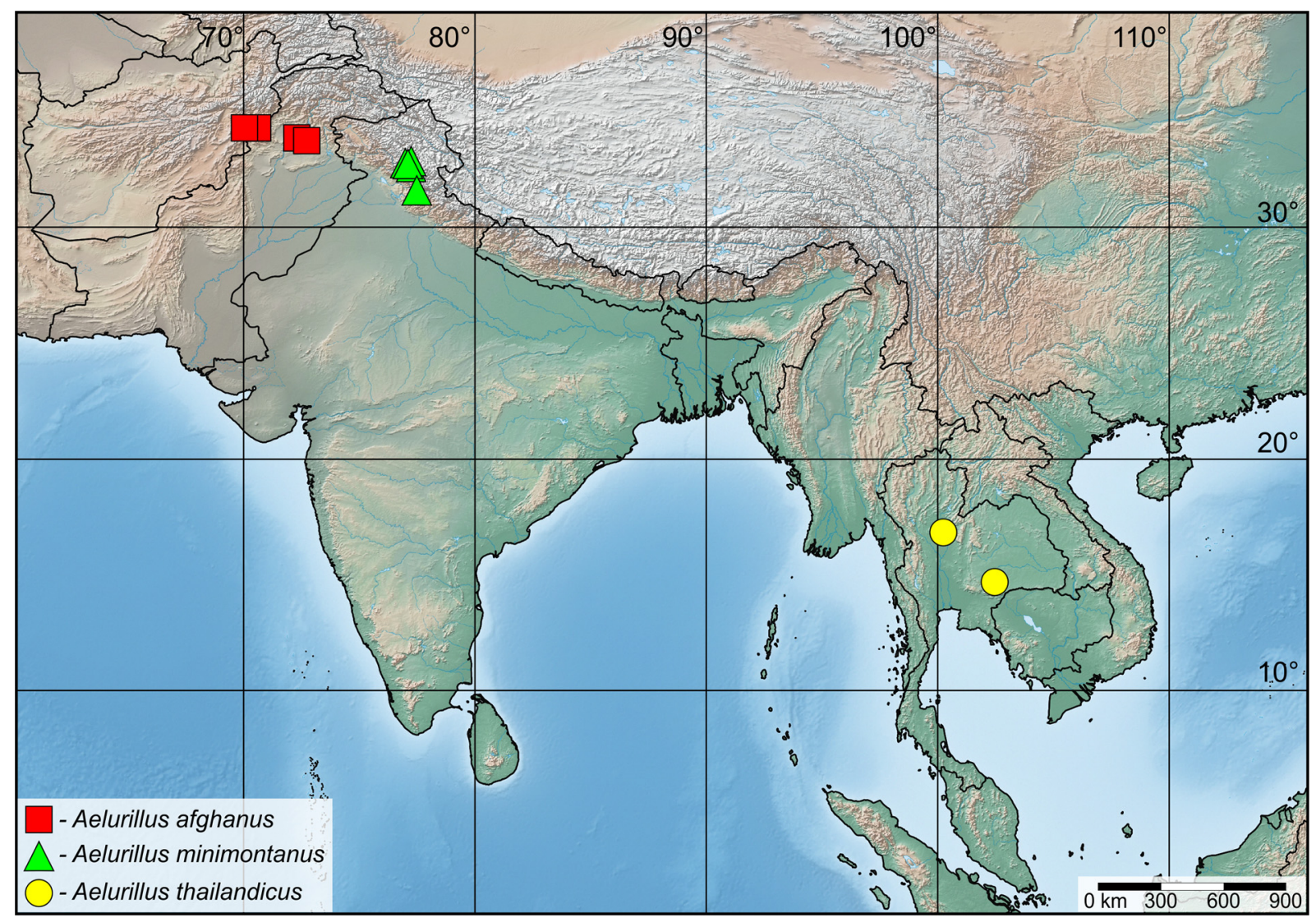

Map. Collecting localities of three Aelurillus species from the 'minimontanus' group.

Карта. Точки сборов трёх видов Aelurillus группы 'minimontanus'.

line in between them (Fig. 11). Chelicerae yellow. Sternum brown-yellow. Abdomen ventrally yellow to yellow-grey; dorsally brown, with a median white longitudinal stripe which is broad near the pedicel tapering towards the caudal part, and with a long brownish stripe in anterior half of the dorsum (Fig. 10). Book-lungs and spinnerets yellow-brown. All legs yellow. Tibiae I yellow to brownish, metatarsi and tarsi I dark brown. Femora I and II ventrally in first third with grey brownish patches, in some specimens without patches. Palps yellow, covered with white hairs. Palpal organs as in Figs 1-7: palpal tibia with three (two sclerotized and one membranous) processes - ventral sclerotized process pointed apically, bending dorsad; dorsal process broad, short, with round tip, slightly bending ventrad (Fig. 2); femur with a prolatero-ventral bulge (Fig. 7); embolus and TA bend ventrad (Figs 4-5); TA tip and membrane between TA and embolus with long teeth (Figs 3-6).

Female: See Azarkina [2006b].

\section{Aelurillus thailandicus sp.n.}

Figs 12-17, 22-36, Map.

TYPES. HоLотуPE OT (ISEA, 001.8306) from Thailand, Phitsanulok Province, Phitsanulok (c. $16^{\circ} 50^{\prime} \mathrm{N}, 100^{\circ} 15^{\prime} \mathrm{E}$ ), bank of Nan river, 9-11.11.2011, V.K. Zinchenko. - PARATYPES: THAILAND: $1 \sigma^{7}$ (ZMMU, Ta-8074), together with the holotype; 1 o (ISEA, 001.8308), Nakhon Ratchasima (Korat) Province, Nong Bun Nak Vil. $\left(14^{\circ} 41.3^{\prime} \mathrm{N}, 102^{\circ} 27.3^{\prime} \mathrm{E}\right), 240 \mathrm{~m}$ a.s.1., 22.05.2010, V.K. Zinchenko.
ETYMOLOGY. The species is named after the country of origin, Thailand.

DIAGNOSIS. By the body coloration and conformation of the copulatory organs, the male of $A$. thailandicus sp.n. is similar to that of $A$. afghanus, but differs from it in the ED conformation: the thin embolus with three apical triangle protuberances in A. thailandicus sp.n. (arrowed in Figs 29, 31 ), whereas the thick embolus without apical protuberances in $A$. afghanus (Figs 4-5); the embolic tip bends prolaterad in $A$. thailandicus sp.n. (Fig. 30), but retrolaterad in $A$. afghanus (Fig. 6). By conformation of the epigyne, the female of $A$. thailandicus sp.n. is similar to those of $A$. afghanus and $A$. minimontanus, but differs from them in the EP shape: EP wide and low, its width two times broader than the wing base in A. thailandicus sp.n. (Fig. 35), whereas EP low, its width 1.5 times broader than the wing base in $A$. afghanus (see Fig. 8 and fig. 1 in Azarkina [2006b]), and EP is high, occupying $4 / 5$ of the epigynal height from its basis to $\mathrm{CO}$ in A. minimontanus (see fig. 56 in Azarkina [2002]). Besides, the female of $A$. thailandicus sp.n. differs from both related species in having the more complex spermathecae having longer insemination ducts (Fig. 36).

COMMENTS. The studied males and the females were collected from different localities in different provinces of Thailand and therefore are provisionally matched together. Yet, it is very likely that they are conspecific indeed.

DESCRIPTION. MAlE (holotype): Carapace 1.50 long, 1.30 wide, 0.90 high at PLE. Ocular area 0.90 long, 0.70 wide anteriorly and 0.65 wide posteriorly. Diameter of AME 


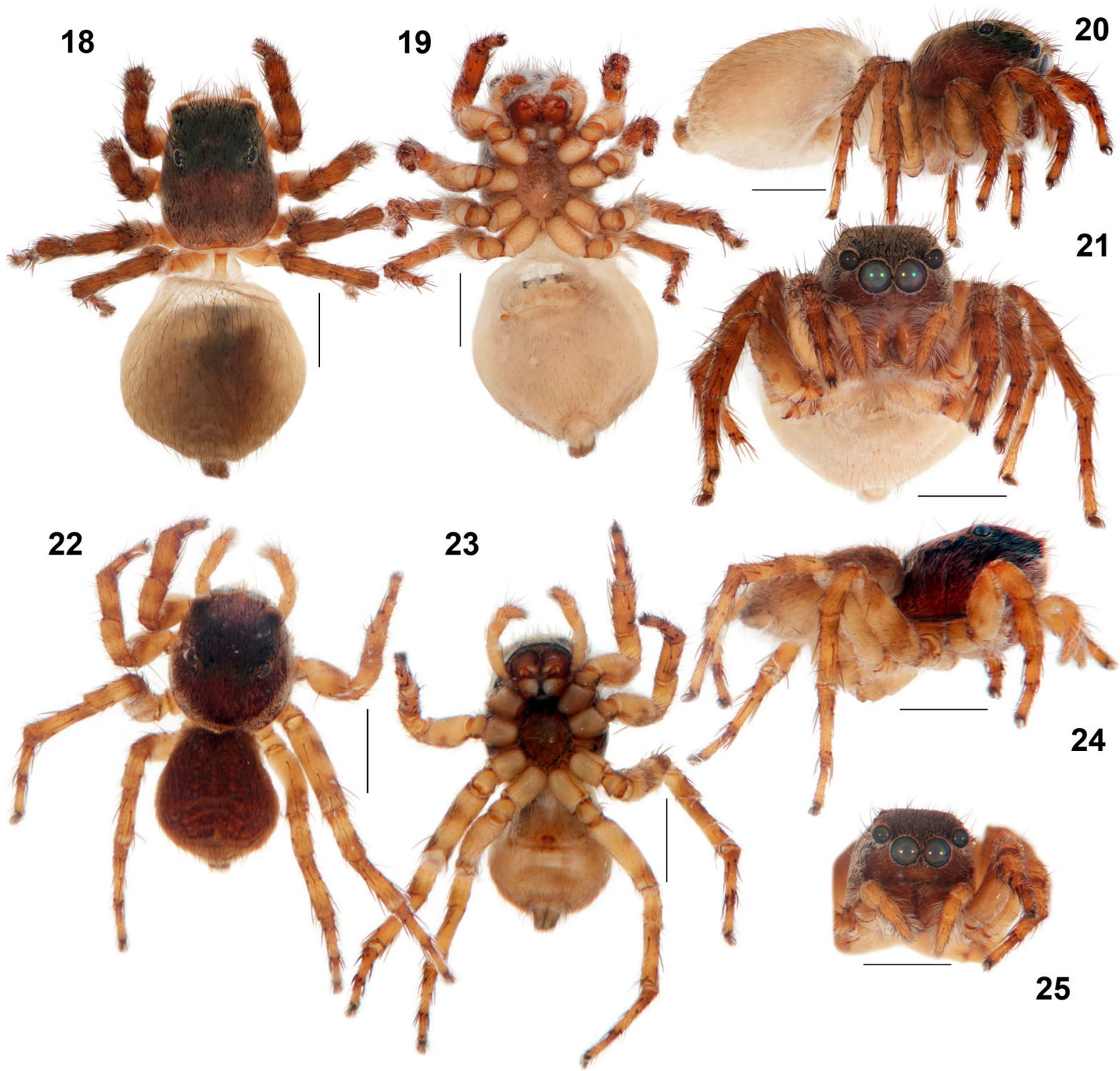

Figs 18-25. General appearance of females of Aelurillus afghanus Azarkina, 2006 (18-21) and A. thailandicus sp.n. (22-25, paratype): 18, 22 - dorsal view; 19, 23 - ventral view; 20, 24 - lateral view; 21, 25 - frontal view. Scale bars: $1 \mathrm{~mm}$.

Рис. 18-25. Внешний вид самок Aelurillus afghanus Azarkina, 2006 (18-21) и A. thailandicus sp.n. (22-25, паратип): 18, 22 дорсально; 19, 23 - вентрально; 20, 24 - латерально; 21, 25 - фронтально. Масштаб: 1 мм.

0.30. Abdomen 1.30 long, 1.10 wide. Cheliceral length 0.40 . Clypeal height 0.20 . Length of leg segments: I $0.70+0.50+$ $0.55+0.40+0.40(2.55) ;$ II $0.80+0.45+0.50+0.40+$ $0.40(2.55) ;$ III $1.20+0.60+0.70+0.65+0.45(3.60) ;$ IV $1.10+0.40+0.60+0.80+0.45$ (3.35). Leg spination: I: Fm d 1-1-3; Pt pr and rt 1; Tb d 1-0-0, pr 1-1-1, rt 0-1-1, v 22-2 ap; Mt pr and rt 1-1 ap, v 2-2 ap. II: Fm d 1-2-5; Pt pr and rt 1 ; Tb d 1-0-0, pr 1-1-1, rt 0-1-1, v 1-1-2 ap; Mt pr and rt 1-1ap, v 2-2 ap. III: Fm d 1-2-5; Pt pr and rt 1; Tb d $1-0-0$, pr and rt 1-1-1-1, v 1-0-2 ap; Mt d 1-1-0, pr and rt 1-0-2 ap, v 2-0-2 ap. IV: Fm d 1-1-4; Pt pr and rt 1; Tb d $1-0-0$, pr and rt 1-1-1-1, v 1-0-2 ap; Mt d 1-1-0, pr 1-12 ap, rt 1-0-2 ap, v 1-1-2 ap. Coloration (in alcohol). Coloration similar to that of $A$. afghanus. Carapace dark brown, with two poorly visible longitudinal white bands, laterally with white broad bands, marginally with white hairs
(Fig. 13). Eye field black, covered with whitish transparent scales, with two longitudinal brown stripes running from AMEs to the thorax end. Cheeks and clypeus brown, covered with dense white hairs. There are two narrow lines of brownish scales running from AMEs to the back side of eye field (Figs 14, 17). Chelicerae brownish yellow. Sternum brown, covered with white hairs (Fig. 15). Abdomen ventrally grey-brown; dorsally dark brown, with white longitudinal median stripe which is broad near the pedicel, tapering towards the caudal part; sides with two short transverse white stripes across the middle part of abdomen (Fig. 13). Spinnerets brown. Book-lungs yellowish brown. All legs brownish yellow. Metatrsi and tarsi I brown. Palps yellow, covered with white hairs. Palpal organs as in Figs 26-33: palpal tibia with three (two sclerotized and one membranous) processes - ventral sclerotized process pointed apically, bending in- 

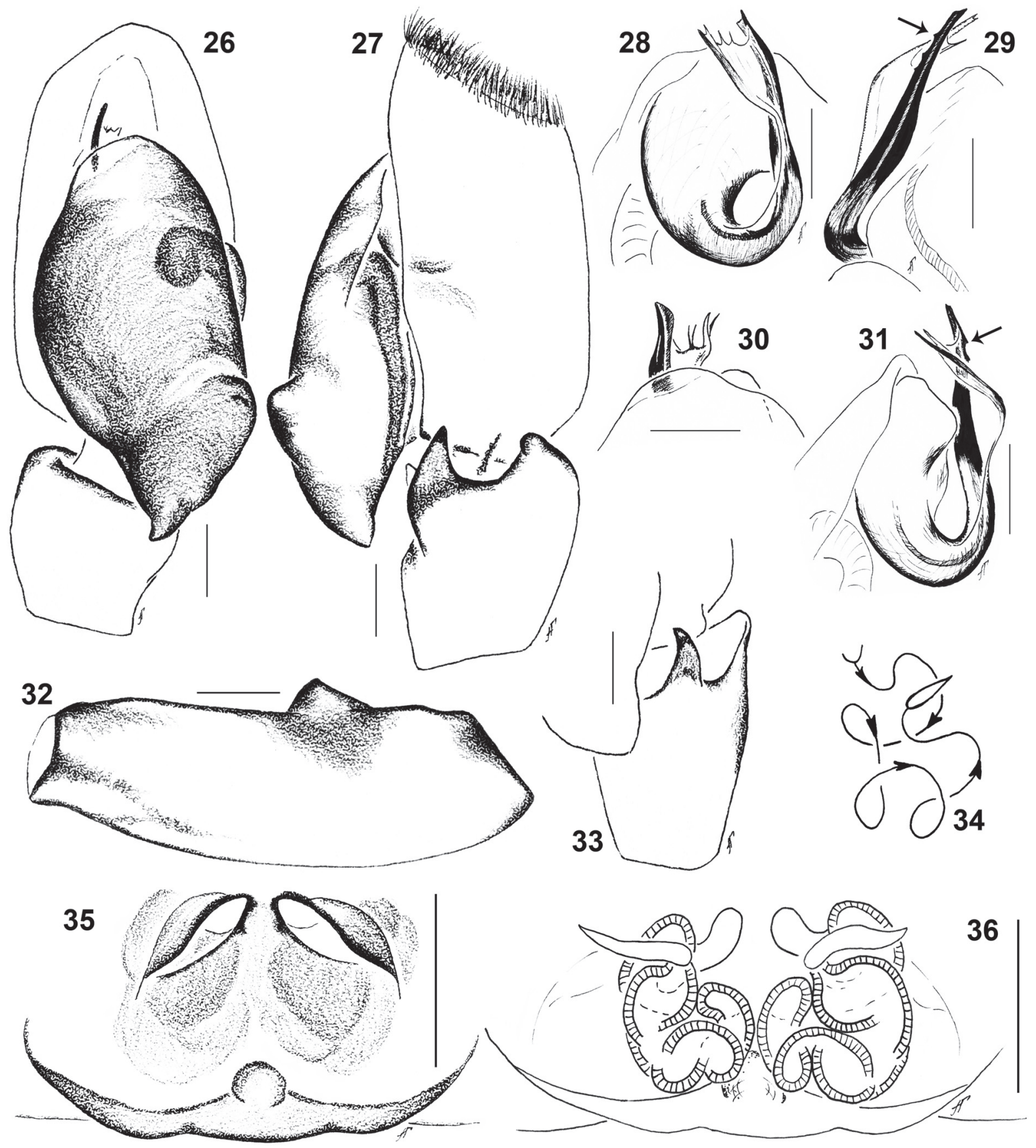

Figs 26-36. Copulatory organs of Aelurillus thailandicus sp.n. (26-27, 32 holotype, 28-31, 33-36 paratypes): 26 - left palp, dorsal view; 27 - ditto, retrolateral view; 28 - ED, dorsal view; 29 - ditto, prolateral view; 30 - ditto, ventral view; 31 - ditto, retrolateral view; 32 - left palpal femur, retrolateral view; 33 - palpal tibia, ventro-retrolateral view; 34 - diagrammatic course of the insemination ducts; 35 - epigyne, ventral view; 36 - spermathecae, dorsal view. Scale bars: $0.1 \mathrm{~mm}$.

Рис. 26-36. Копулятивные органы Aelurillus thailandicus sp.n. (26-27, 32 голотип, 28-31, 33-36 паратипы): 26 - левая пальпа, вентрально; 27 - то же, ретролатерально; 28 - эмболюсный отдел, дорсально; 29 - то же, пролатерально; 30 - то же, вентрально; 31 - то же, ретролатерально; 32 - бедро левой пальпы, ретролатерально; 33 - голень пальпы, вентро-ретролатерально; 34 - схема оплодотворительных каналов; 35 - эпигина, вентрально; 36 - сперматека, дорсально. Масштаб: 0,1 мм.

ward and dorsad; dorsal process broad, short, with round tip, slightly bending outward and ventrad (Figs 27, 33); femur with a prolatero-ventral bulge (Fig. 32); embolus and TA bend ventrad (Figs 29, 31); TA tip and membrane between TA and embolus with long teeth (Figs 28-31).
Female (paratype): Carapace 1.80 long, 1.50 wide, 1.00 high at PLE. Ocular area 1.00 long, 1.10 wide anteriorly and 1.05 wide posteriorly. Diameter of AME 0.30. Abdomen 1.70 long, 1.50 wide. Cheliceral length 0.45. Clypeal height 0.20 . Length of leg segments: I. $0.90+0.60+0.55+0.40+$ 


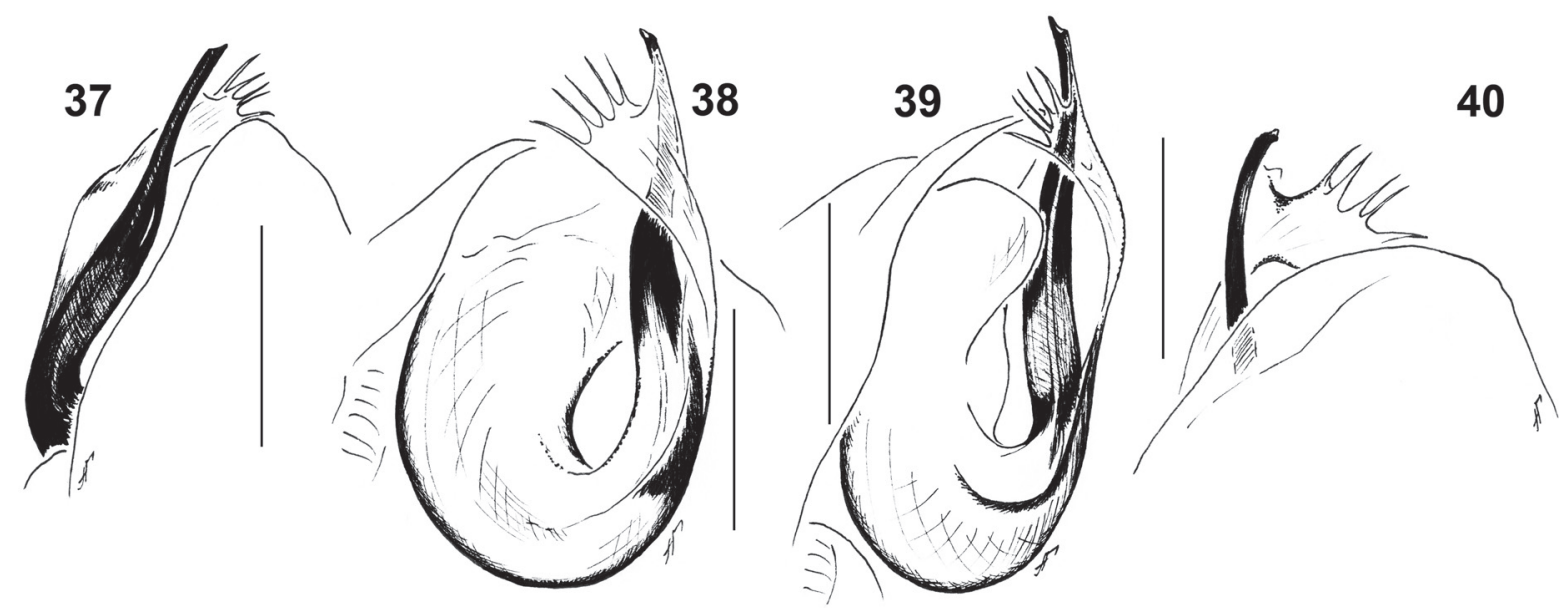

Figs 37-40. EO of Aelurillus minimontanus Azarkina, 2002 (paratype, ISEA 001.705): 37 - ED, prolateral view; 38 — ditto, dorsal view; 39 - ditto, retrolateral view; 40 - ditto, ventral view. Scale bars: $0.1 \mathrm{~mm}$.

Pис. 37-40. EO Aelurillus minimontanus Azarkina, 2002 (паратип, ISEA 001.705): 37 - эмболюсный отдел, пролатерально; 38 — то же, дорсально; 39 — то же, ретролатерально; 40 — то же, вентрально. Масштаб: 0,1 мм.

$0.40(2.85) ;$ II $0.90+0.60+0.50+0.35+0.35(2.70) ;$ III $1.50+0.70+0.65+0.80+0.50(4.15) ; \operatorname{IV} 1.20+0.60+$ $0.75+0.90+0.50$ (3.95). Leg spination: I: Fm d 1-1-2; Tb pr $0-2$, rt $0-1$, v 1-1-2 ap; Mt pr and rt 1-1 ap, v 2-2 ap. II: Fm d 1-1-2; Tb pr and rt $0-1, \mathrm{v} 2-1-1$ ap or $1-1-2$ ap; Mt pr and rt 1-1ap, v 2-2 ap. III: Fm d 1-1-3; Pt pr and rt 1; Tb d $1-0-0$, pr and rt $0-1-1$, v $0-0-2$ ap; Mt d $1-0-0$, pr and rt 1-0-2 ap, v 2-0-2 ap. IV: Fm d 1-1-1; Pt pr and rt 1; Tb d $1-0-0$, pr and rt $0-1-1, \mathrm{v} 1-1-2$ ap or $2-0-2$ ap; Mt d $1-1-$ 0 , pr 1-1-2 ap, rt 1-0-2 ap, v 1-1-2 ap. Coloration (in alcohol). Carapace brown, with dark brown eye field, covered with whitish transparent scales, with no pattern (Fig. 22). Sternum brown, covered with short white hairs. Labium and endites yellow-brown, pale apically. Cheeks and clypeus brown, covered with sparse white hairs. There are two narrow lines of brownish scales running from AMEs to the back side of eye field (Fig. 25). Chelicerae brown. Abdomen brownish yellow ventrally (Fig. 23), brown dorsally, covered with short white hairs and dark brown bristles, without clear pattern (Fig. 22). Spinnerets brown book-lungs greyyellow. All legs and palps brownish-yellow, with brown patches and semi-rings. Epigyne and spermathecae as in Figs 34-36: EP low and wide, twice as wide as the base of the wings, round in the centre (Fig. 35); spermathecae compact, IDs long, with numerous twists (Figs 34, 36).

\section{Discussion}

A. thailandicus sp.n. is the first record of Aelurillus from Indochina and the third finding of Aelurillina in SE Asia. Hitherto, two Aelurillina species were described from Vietnam: P. pisarskii and S. abramovi; the latter was later recorded from Thailand as well [Logunov, Azarkina, 2018]. A small number of the Aelurillina in the region at hand is likely due to its poor state of knowledge. For instance, the neighbouring faunas of India and China contain 16 species in four genera and 16 species in five genera correspondingly [WSC, 2019]. Perhaps, with a more detailed study of the region at hand at least representatives of the genera
Langona Simon, 1901 and Phlegra Simon, 1876 will be encountered.

Acknowledgements. I am obliged to D.V. Logunov (Manchester, UK) for his kind linguistic help and critical comments that helped me to improve the ms. I also with to thank W. Chotwong (Bangkok, Thailand) for providing me with some literature. I am grateful to V.K. Zinchenko (Novosibirsk, Russia) for collecting specimens of a new species. This work was supported by the Federal Fundamental Scientific Research Programme for 2013-2020 (No. AAAA-A16116121410121-7).

\section{References}

Azarkina G.N. 2002. New and poorly known species of the genus Aelurillus Simon, 1884 from central Asia, Asia Minor and the eastern Mediterranean (Araneae: Salticidae) // Bulletin of the British Arachnological Society. Vol.12. Pt.6. P.249-263.

Azarkina G.N. 2006a. [Revision of the genus Aelurillus Simon, 1884 (Salticidae) of the world]. Synopsis of PhD thesis. Novosibirsk: ISEA SB RAS. 26 pp. [in Russian]

Azarkina G.N. 2006b. Four new species of the genus Aelurillus Simon, 1884 (Araneae: Salticidae) // Deltshev Ch., Stoev P. (eds.) European Arachnology 2005. Acta Zoologica Bulgarica Supplement 1. 63-72.

Azarkina G.N., Mirshamsi O. 2014. Description of a new Aelurillus species from Khorasan province of Iran, with comments on A. concolor Kulczyñski, 1901 (Araneae: Salticidae) // Zoology in the Middle East. Vol.60. No.1. P.82-91.

Azarkina G.N., Zamani A. 2019. The Aelurillina Simon, 1901 (Aranei: Salticidae) of Iran: a check-list and three new species of Aelurillus Simon, 1884 and Proszynskiana Logunov, 1996 // Arthropoda Selecta. Vol.28. No.1. P.83-97. doi:10.15298/arthsel. 28.1.07

Azarkina G.N., Zoumides C., Hadjiconstantis M. 2018. First description of the female of Aelurillus cypriotus Azarkina 2006 (Araneae: Salticidae) // Acta Arachnologica. Vol.67. No.1. P.49-54. doi:10.2476/asjaa.67.49

Benjamin S.P. 2004. Taxonomic revision and phylogenetic hypothesis for the jumping spider subfamily Ballinae (Araneae, Salticidae) // Zoological Journal of the Linnean Society. 142. P.1-82. 
Benjamin S.P. 2010. Revision and cladistic analysis of the jumping spider genus Onomastus (Araneae: Salticidae) // Zoological Journal of the Linnean Society. Vol.159. No.3. P.711-745. doi:10.1111/j.1096-3642.2009.00580.x

Chotwong W., Tanikawa A. 2013. Four spider species of the families Theridiidae, Araneidae, and Salticidae (Arachnida; Araneae) new to Thailand // Acta Arachnologica. Vol.62. No.1. P.15. doi:10.2476/asjaa.62.1

Giebel C.G. 1863. Drei und zwanzig neue und einige bekannte Spinnen der Hallischen Sammlung // Zeitschrift für die Gesammten Naturwissenschaften. Bd.21. S.306-328.

Logunov D.V. 2017. New species and records in the genus Synagelides Strand in Bösenberg et Strand, 1906 (Aranei: Salticidae) from the Oriental region // Arthropoda Selecta. Vol.26. No.4. P.315-322. doi:10.15298/arthsel. 26.4.06

Logunov D.V. 2019. Taxonomic notes on the Harmochirina Simon, 1903 from South and South-East Asia (Aranei: Salticidae) // Arthropoda Selecta. Vol.28. No.1. P.99-112. doi:10. 15298/arthsel. 28.1.08

Logunov D.V., Azarkina G.N. 2008. New species of and records for jumping spiders of the subfamily Spartaeinae (Aranei: Salticidae) // Arthropoda Selecta. Vol.16. No.2. P.97-114.

Logunov D.V., Azarkina G.N. 2018. Redefinition and partial revision of the genus Stenaelurillus Simon, 1886 (Arachnida, Araneae, Salticidae) // European Journal of Taxonomy. No.430. P.1-126. doi: 10.5852/ejt.2018.430.

Logunov D.V., Hereward J. 2006. New species and synonymies in the genus Synagelides Strand in Bösenberg \& Strand, 1906 (Araneae: Salticidae) // Bulletin of the British Arachnological Society. Vol.13. Pt.8. P.281-292.

Logunov D.V., Marusik Yu.M. 2014. Taxonomic notes on the genus Eupoa Żabka, 1985 (Arachnida, Araneae, Salticidae) // ZooKeys. Vol.410. P.63-93. doi:10.3897/zookeys.410.7548
Metzner H. 2019. Jumping spiders (Arachnida: Araneae: Ssalticidae) of the world (accessed on 19.05.2019); online at https:// www.jumping-spiders.com

Ono H. 1988. A revisional study of the spider family Thomisidae (Arachnida, Araneae) of Japan. Tokyo: National Science Museum. 252 pp.

Prószyński J., Deeleman-Reinhold C.L. 2012. Description of some Salticidae (Aranei) from the Malay archipelago. II. Salticidae of Java and Sumatra, with comments on related species // Arthropoda Selecta. Vol.21. No.1. P.29-60.

Roewer C.F. 1955. Katalog der Araneae von 1758 bis 1940. Bruxelles. Bd.2a. S.1-1751.

Shorthouse D.P. 2010. SimpleMappr, an online tool to produce publication-quality point maps. http://www.simplemappr.net (accessed on 13.05.2019)

WSC. 2019. World Spider Catalog. Version 20.0. Natural History Museum Bern, online at http://wsc.nmbe.ch, accessed on 19.05.2019. doi: $10.24436 / 2$.

Yamasaki T., Ahmad A.H. 2013. Taxonomic study of the genus Myrmarachne of Borneo (Araneae: Salticidae) // Zootaxa. Vol.3710. No.6. P.501-556. doi:10.11646/zootaxa.3710.6.1

Żabka M. 1985. Systematic and zoogeographic study on the family Salticidae (Araneae) from Viet-Nam // Annales Zoologici PAN. T.39. No.11. P.197-485.

Żabka M., Gardzińska J. 2017. Salticidae of Thailand. Part 1, genera Plexippus C. L. Koch, 1846 and Burmattus Prószyñski, 1992 // Annales Zoologici PAN. T.67. No.2. P.229-242. doi:10.3161/00034541ANZ2017.67.2.004

Zhang Y.Q., Song D.X., Zhu M.S. 1992. [Notes on a new and eight newly recorded species of jumping spiders in Guangxi, China (Araneae: Salticidae)] // Journal of the Guangxi Agricultural College. Vol.11. No.4. P.1-6 [in Chinese, with English abstract].

Responsible editor D.V. Logunov 